REVIEW

\title{
Bone mass acquisition in healthy children
}

\author{
J H Davies, B A J Evans, J W Gregory
}

Arch Dis Child 2005;90:373-378. doi: 10.1136/adc.2004.053553

\begin{abstract}
Although $80 \%$ of the variance in bone mass is determined genetically, there are many other factors which influence the accumulation of bone in early life and affect future risks of osteoporosis. This review considers the genetic, fetal, and environmental influences on bone mass acquisition in healthy children, and highlights important areas where paediatricians may have a role by counselling children and their families to adopt a healthy lifestyle which promotes bone health.
\end{abstract}

See end of article for
authors' affiliations
........................
Correspondence to:
Dr J H Davies, Department
of Child Health, Cardiff
University, Heath Park,
Cardiff CF14 4XN, UK;
daviesih@cf.ac.uk

Accepted 7 October 2004
E ven though the clinical consequences of adverse bone health are largely seen in old age, evidence is accumulating that many predisposing factors to osteoporosis arise in childhood. Given an ageing population, an increase in osteoporosis related fractures has enormous economic implications. For example, in the UK $£ 280$ million is spent annually treating osteoporotic hip fractures alone. ${ }^{1}$ In children as in adults, fracture rates have been shown to be higher in individuals with a lower bone mineral density (BMD). ${ }^{2}{ }^{3}$ Therefore, an understanding of the many influences on BMD is important for deciding rational strategies for optimising bone health during childhood.

There are two functionally distinct phases of bone development. The first is skeletal patterning which occurs during the embryonic period, when the position and shape of the various skeletal elements is determined by the expression of numerous regulatory genes and by local growth factors. The second phase begins with mineralisation, the location of which is influenced by mechanical strain. A view is emerging (the mechanostat theory) that rather than just being a passive recipient to external stimuli, bone tissue regulates itself with the aim of maintaining its structural integrity and strength. ${ }^{4}$ Supporting evidence has come from recent developments in genetic and molecular studies which have identified new local and central homoeostatic mechanisms controlling bone mass.

This article will review the genetic, fetal, and environmental influences on bone mass acquisition during childhood and will highlight recent discoveries that have shed light on to how bone mass is maintained. Reference is made to the terms bone mass and BMD. Bone mass refers to the weight of bone and may be influenced by bone size. By contrast, BMD refers to bone mass adjusted for bone volume.

\section{CHANGES IN BONE MASS DURING CHILDHOOD}

During skeletal growth, the balance of cellular activity is in favour of net bone formation, and at peak bone mass the amount of osteoclastic bone resorption is exactly matched by the amount of osteoblastic new bone formation. Peak bone mass is the maximal amount of bone mineral accrued within bone during childhood and adolescence plus the consolidation that continues beyond the attainment of final height. ${ }^{5}$ Dual energy $x$ ray absorptiometry (DEXA) imaging indicates that there is an increase in bone mass throughout childhood with a marked acceleration in accumulation at puberty (fig 1 ). ${ }^{6}$ The increase in BMD that occurs following puberty is confirmed by quantitative computerised tomography $(\mathrm{CT}) .^{78}$ This latter technique has the advantage of measuring volumetric BMD and is less influenced by bone size than DEXA which tends to underestimate BMD in small subjects and overestimate it in larger individuals. ${ }^{9}$ During growth, accrual of bone mass mainly results from increases in bone size, with very small changes in volumetric BMD. ${ }^{8}{ }^{10}$ Physiological adaptation of bone to the local muscle force is particularly important in prepubertal children as some of the age dependent increase in BMD in these individuals is attributable to an increase in local muscularity. ${ }^{11}{ }^{12}$

Longitudinal studies of changes in bone mass during growth have confirmed that in girls, the greatest increases in bone mass occur between the ages of 12-15 years, compared with 14-17 years in boys. ${ }^{6}$ Although the rate of change in bone mass slows dramatically by the age of 1618 years in females and 17-20 years in males, uncertainty remains about the age at which accumulation of new bone stops and peak bone mass is attained. Some cross-sectional studies have suggested that in adult women, bone mass continues to increase during the third decade to reach a peak between 30 and 35 years. ${ }^{13}$ Others, however, have suggested that bone mass reaches a peak between the ages of 25 and 35 years. ${ }^{14}$ Although optimising the genetic potential for peak bone mass is thought to delay the onset of osteoporosis and fractures in later life, longitudinal studies have yet to confirm this hypothesis (fig 1).

\section{GENETIC DETERMINANTS OF BONE MASS}

Twin studies indicate that genetic predisposition determines up to $80 \%$ of peak bone mass, whereas the remaining $20 \%$ is modulated by environmental factors and sex hormone levels during puberty. ${ }^{15}$ This genetic influence is consistent with the findings that BMD is reduced in the daughters of osteoporotic women ${ }^{16}$ and in 


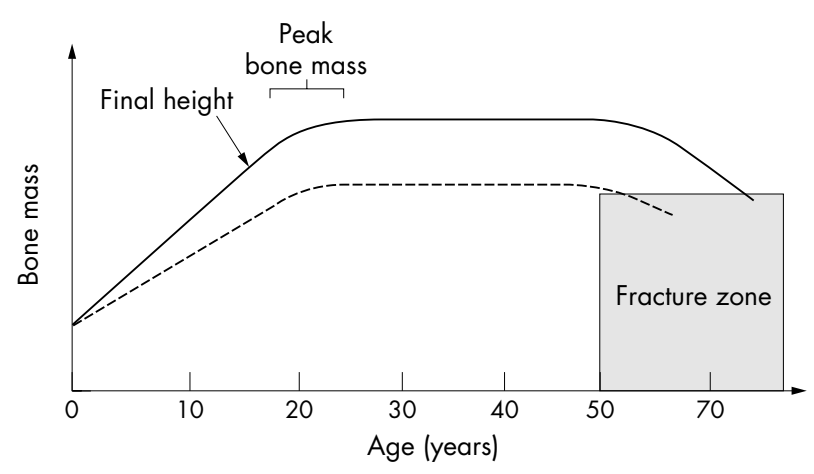

Figure 1 Schematic representation of the changes of bone mass with age as measured by DEXA. The dotted line shows the theoretical consequence of a reduction in peak bone mass.

men and women with first degree relatives who have osteoporosis. ${ }^{17}$ A large number of genes are responsible for determining bone mass, and polymorphisms of many of these have been suggested to influence bone mass (table 1). However, the magnitude of the effects of most of these polymorphisms on bone density in childhood have not been evaluated.

\section{Vitamin D receptor gene polymorphisms}

Several studies have examined the influence of vitamin D receptor alleles on BMD in children. In adult women, vitamin D receptor polymorphisms contribute to a relatively small variation in BMD. ${ }^{18}{ }^{19}$ By contrast, in children compared with adults, vitamin D receptor polymorphisms account for a greater difference when femoral and vertebral BMD are compared between those with homozygous recessive (bb) and those with dominant genotypes (BB), ${ }^{20}{ }^{21}$ suggesting that these polymorphisms have a greater influence on BMD during childhood. In a study of prepubertal girls, dietary calcium intake also correlated with change in BMD in those with homozygous dominant and heterozygous vitamin D receptor $(\mathrm{BB}$ and $\mathrm{Bb})$ genotypes but not in those with the homozygous (bb) genotype. ${ }^{21}$ These data provide an explanation for why there is a variation in response to calcium supplementation in terms of BMD accrual in children.

\section{Type I collagen gene polymorphisms}

A polymorphism in the regulatory region of the type I collagen gene, COLIAl, affects the binding site for the transcription factor, Specificity protein 1 (Spl). ${ }^{22}$ This polymorphism was shown to be associated with reduced

Table 1 Gene polymorphisms that influence bone mass

\begin{tabular}{llll}
\hline Receptors & $\begin{array}{l}\text { Hormones/ } \\
\text { cytokines }\end{array}$ & Enzymes & $\begin{array}{l}\text { Bone matrix } \\
\text { proteins }\end{array}$ \\
\hline $\begin{array}{l}\text { Vitamin } D^{*} \\
\text { Oestrogen }(E R \alpha)^{*}\end{array}$ & $\begin{array}{lll}\text { IL-6* } \\
\text { IGF-1* }\end{array}$ & $\begin{array}{l}\text { Aromatase } \\
\text { Collagenase }\end{array}$ & $\begin{array}{l}\text { COLIA1* } \\
\text { Osteocalcin* }\end{array}$ \\
LRP-5* & BMP-4 & \\
Leptin* & PTH & & \\
Androgen & TNF- $\alpha$ & & \\
Glucocorticoid & TGF- $\beta$ & & \\
PTH & Osteoprotegerin & \\
TNF & & & \\
Calcium & & & \\
Calcitonin & & \\
TSH & & \\
\end{tabular}

*Indicates influence on BMD shown during childhood. BMP, bone morphogenetic protein; COLIAI, type I collagen; IGF-1, insulin-like growth factor 1; IL, interleukin; LRP-5, low density lipoprotein related protein 5; PTH, parathyroid hormone; TGF, transforming growth factor; TNF, tumour necrosis factor; $\mathrm{TSH}$, thyroid stimulating hormone.
BMD and osteoporotic fractures in pre- and postmenopausal women. ${ }^{22}$ The same polymorphism was associated with decreased vertebral BMD in prepubertal girls with the heterozygous and homozygous recessive genotypes. ${ }^{23}$ In adolescents, polymorphisms of the oestrogen receptor, interleukin- 6 and osteocalcin genes have also been shown to be independent predictors of BMD. ${ }^{24-26}$

\section{Low density lipoprotein receptor related protein 5 (LRP5)}

Recent studies of heritable skeletal disorders have identified a new mechanism of bone mass maintenance. A kindred with an autosomal dominant inherited high bone mass phenotype, with typical features of a square jaw and torus palatinus (an exostosis in the midline of the hard palate), was found to be the result of a mutation of the gene encoding for low density lipoprotein receptor related protein 5 (LRP5). ${ }^{27}$ In affected individuals, serum markers of bone formation were increased whereas bone resorption markers were normal. The LRP5 protein normally mediates the binding of a growth factor, Wnt, to its receptor which allows activation of intracellular signalling to promote osteoblastic differentiation (fig 2, left). In vitro studies have shown that this LRP5 mutation prevented the binding of a natural inhibitor of Wnt signalling, Dickkopf-1 (DKK-1), thus leading to unopposed Wnt activity (fig 2, centre and right). ${ }^{27}$ Concordant with this finding was the discovery that in the osteoporosis-pseudoglioma syndrome, characterised by low bone mass with childhood fractures and abnormal eye development, the phenotype was the result of an inherited loss of function of the LRP5 gene ${ }^{28}$ leading to inhibition of Wnt signalling. Given that non-syndromic high bone mass maps to the region of $11 q 12-13,{ }^{29}$ the region which encodes LRP5, ${ }^{30}$ it is possible that LRP5 polymorphisms are significant contributors to the natural variation in bone density in normal children. ${ }^{31}$ Furthermore, antagonism of DKK-1 action provides a novel therapeutic opportunity for the treatment of osteoporosis.

\section{FETAL INFLUENCES ON BONE MASS}

The association between low birth weight and a low BMD in adulthood suggests that intrauterine programming contributes to the subsequent risk of osteoporosis in later life. In longitudinal studies of adults, a significant association between weight at 1 year (a marker of intrauterine and early postnatal environment) and adult bone mineral content at the lumbar spine and femoral neck have been shown. ${ }^{32}$ These findings were significant even after adjusting for influences of adult body size and lifestyle. Furthermore, the genetic influences on adult bone size and BMD may be modified by undernutrition in infancy, as evidenced by the significant interaction between the vitamin $\mathrm{D}$ receptor genotype and birth weight, the interaction of which was a determinant of lumbar spine BMD in adulthood. ${ }^{33}$ A low childhood growth rate and tall maternal height are associated with an increased risk of hip fracture in late adulthood. ${ }^{34}$ The same study reported that the individuals who experienced fractures in later life, were short at birth but had normal height by 7 years of age, suggesting that the normal lag in bone mineralisation behind linear growth is exacerbated in these individuals.

Some studies suggest there maybe intrauterine programming of the hypothalamic-pituitary axis. For instance, there is an association between low birth weight and both low BMD and median stimulated growth hormone $(\mathrm{GH})$ concentrations in adulthood. ${ }^{35}{ }^{36}$ Others have found a significant relation between size at birth and cortisol secretion in adult life $^{37}$ which may be a determinant of BMD in adulthood. ${ }^{38}$ Parental birth weight and maternal cigarette smoking, maternal thinness, and activity during pregnancy were found to independently influence skeletal growth and 

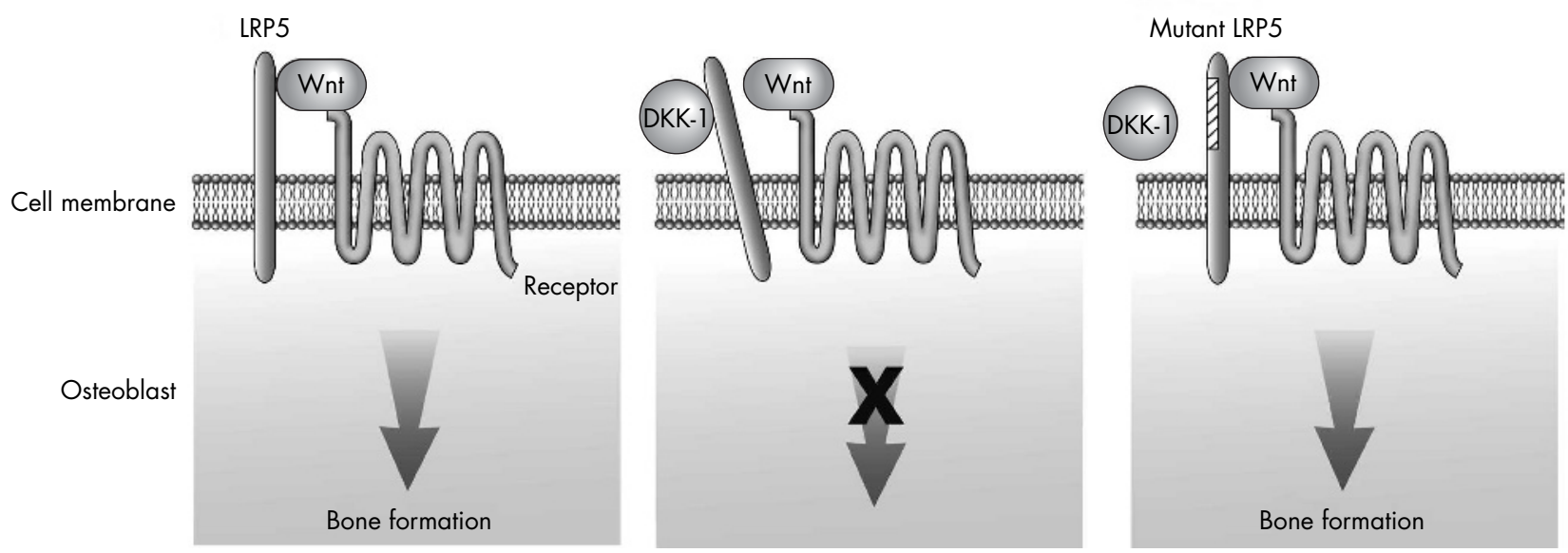

Figure 2 Left: in the absence of DKK-1, LRP5 interacts with the Wnt receptor and activates intracellular signalling leading to bone formation. Centre: DKK-1 prevents this interaction and an active signalling complex does not occur. Right: mutant LRP5 preferentially forms complexes with Wnt, leading to constitutive activation of Wnt signalling and bone formation.

mineralisation in utero, as evidenced by correlation of these factors with neonatal BMD. ${ }^{39}$ This latter study shows the importance of the interplay between genetic and environmental factors in utero on prenatal skeletal development, although the mechanistic basis for these observations has yet to be established.

Animal studies have focused on maternal undernutrition as a causal factor for how fetal programming leads to reduced BMD in later life. These studies have confirmed that intrauterine exposure to maternal protein deficiency lead to offspring with reduced bone mineral content and bone area in adulthood. ${ }^{40}$ Furthermore, the bone marrow mesenchymal stem cells (that is, osteoblast precursors) of these offspring were adversely affected as evidenced by a reduction in colony formation, proliferation and differentiation coupled with an impaired responsiveness to anabolic factors such as GH, IGF-1, and 1,25 dihydroxyvitamin $\mathrm{D}_{3} \cdot{ }^{41}$

\section{HORMONAL INFLUENCES}

During childhood, GH is an important hormonal contributor to bone mass accrual before and after the attainment of final height. ${ }^{42} 43$ Levels of GH and insulin-like growth factor 1 (IGF-1) increase dramatically during puberty, augmented by the increasing levels of sex steroids. GH action on bone is mainly mediated through IGF-1, which positively effects bone turnover by stimulating osteoblast proliferation and differentiation. The prepubertal increase in adrenal androgens, specifically dehydroepiandrosterone metabolites, also have beneficial effects on the accretion of bone strength. ${ }^{11}$ New bone formation at puberty is likely to be the result of a further increase in muscularity and also the anabolic effects of the sex hormones on bone accretion. ${ }^{6}$ During the pubertal period, oestradiol has important effects, not just from increasing bone density but also by modulating bone remodelling by suppression of bone turnover at the endocortical surface leading to an increase in cortical thickness. ${ }^{44}$

\section{PHYSICAL ACTIVITY}

Exercise exerts a positive effect on bone mass as young women involved in high impact or weight bearing activity (such as gymnastics) during both childhood and adolescence, have a higher bone mass than those not participating in such activity. ${ }^{35} 45$ The timing of an exercise intervention during childhood is also important. Exercise initiated during the prepubertal or early pubertal years appears to be the most beneficial to improving bone mass. A simple school based jumping programme given during the prepubertal years has been shown to significantly improve bone mass at the hip and spine..$^{45-47}$ These advantageous effects were sustained for up to seven months after the exercise intervention had been discontinued. ${ }^{48}$ In peripubertal girls, a similar high impact, circuit based jumping programme also increased bone mineral content at the hip and spine ${ }^{49}$ and to a greater extent than that observed in prepubertal children. ${ }^{50}$ Furthermore, in a study of females that played racket sport to a national level, there was a twofold increase in bone mineral content in those that started playing at or before menarche when compared to those starting later. ${ }^{51}$

Thus physical activity during early childhood and adolescence appears to be an important predictor of peak bone mass which may account for up to $17 \%$ of the variance in BMD between individuals in their late 20s. ${ }^{52}$ It is less clear however, whether physical activity in youth is translated into a reduced fracture risk in old age. A recent study has shown that fracture incidence in elderly former soccer players was no different from controls. ${ }^{53}$ Although BMD was higher in the years following retirement from soccer, cessation of exercise resulted in an accelerated loss of bone density, such that those who had been retired for over 35 years and aged over 60 years had no significant residual benefit in BMD. It can be hypothesised that the exercise induced benefits of optimising peak bone mass may only be short term ${ }^{54}$ and prospective longitudinal studies are needed to clarify this important issue.

\section{NUTRITIONAL INFLUENCES}

\section{Nutritional sufficiency}

Adolescent females who recover from anorexia nervosa have persistent osteopenia ${ }^{55}$ and a greater reduction in spinal BMD compared to those with the adult onset of the disease, ${ }^{56}$ suggesting that nutritional inadequacy predisposes to osteopenia. Reduced IGF-1 expression, ${ }^{57} \mathrm{GH}$ resistance, ${ }^{58}$ and hypogonadism resulting from undernutrition are contributing factors in this disorder.

Over-nutrition may also influence bone formation as overweight children have an increased predisposition to reduced BMD and fracture. ${ }^{359}$ There is increasing evidence that the hormone leptin, secreted by adipocytes, is involved in bone formation. Studies in normal children have shown a positive correlation between serum leptin levels and adiposity $^{60}{ }^{61}$ whereas leptin deficiency or resistance is associated with obesity. ${ }^{62-64}$ In children, cerebrospinal fluid (CSF) leptin 
concentrations are correlated with plasma leptin concentrations and only free (biologically active) leptin is detectable in CSF. ${ }^{65}$ These findings are interesting given that leptin has recently been shown in experimental studies to have a role in both the central and peripheral regulation of bone formation. Mice lacking either the functional leptin gene or the gene for its receptor have high bone densities, and intracerebroventricular administration of leptin to leptin deficient animals resulted in marked bone loss. ${ }^{66}$ Further animal studies indicated that the downstream mediator of leptin was the sympathetic nervous system, the activation of which lead to reduced bone mass. ${ }^{67}$ By contrast, in vitro studies suggest that leptin has direct beneficial effects on osteoblasts including stimulation of type I collagen synthesis, human osteoblastic differentiation, and matrix mineralisation. ${ }^{68} 69$

\section{Calcium}

A high intake of milk during childhood and adolescence is associated with increased bone mass at maturity. ${ }^{70}{ }^{71}$ The amount of dietary calcium consumption exerts a positive dose dependent effect on spinal bone mass in young women ${ }^{72}$ which is consistent with the known anabolic effect of calcium on the growing skeleton. Data such as these prompted studies of calcium supplementation in healthy children. In a study of identical twins of mean age 10 years, calcium citrate supplementation over three years significantly increased bone mass in the supplemented children when compared to their non-supplemented siblings. ${ }^{73}$ Others have shown in young children that calcium supplementation also augments the bone response to physical activity, resulting in greater cortical thickness and area. ${ }^{74}$ Milk extracted calcium phosphate, given for nearly one year, also significantly increased bone mass accrual in prepubertal girls. ${ }^{75}$ This beneficial effect was maintained three years after discontinuation of the supplementation, at a time when the subjects were pubertal or postpubertal. ${ }^{76}$ By contrast, following the completion of puberty in the calcium citrate supplemented twin studies, BMD was no different from sibling controls. ${ }^{73}$ It is possible that calcium phosphate extracted from milk may have additional anabolic properties over other calcium salts. If this is the case, a simple measure such as dietary supplementation with milk extracted calcium phosphate could favourably alter bone mass acquisition during childhood with lasting effects into early adulthood.

\section{Vitamin D}

Vitamin D is an essential dietary factor necessary for normal mineralisation of osteoid tissue. Evidence is accumulating of a resurgence of vitamin $\mathrm{D}$ deficiency in Western society, ${ }^{77}$ particularly in ethnic minorities. ${ }^{78}$ There is increasing support for this issue to be addressed by a renewed public health campaign to prevent the likely resultant adverse effects on children's bone health. ${ }^{78}{ }^{79}$ There are recent published guidelines for the amount of vitamin D required to prevent vitamin D deficiency. ${ }^{80}$ Vitamin D supplementation, even when given during infancy, has been associated with an increase in BMD in prepubertal children. ${ }^{81}$

\section{Other dietary factors}

The consumption of vegetables such as onions is associated with inhibition of bone resorption leading to an increase in bone mass, although the pharmacologically active compound(s) leading to this effect remain unidentified. ${ }^{82}$ By contrast, a high consumption of carbonated beverages may lead to a reduction in BMD during adolescence. ${ }^{83}$ This effect is likely to be the result of milk displacement from the diet rather than from the direct effects on bone from the components of carbonated soft drinks such as caffeine, phosphorus, or glucose.

\section{FRACTURES IN CHILDHOOD AND ADOLESCENCE}

Fracture incidence in children peaks between the ages of 1015 years. Fractures in this age group are related to bone strength which is a consequence of not just bone mass but also bone microarchitecture, biomechanics, and bone geometry such as cortical thickness. ${ }^{84} 85$

Distal forearm fractures are the commonest childhood fracture and the incidence is increasing. ${ }^{86}$ It has been shown in healthy girls that each single standard deviation reduction in total body areal BMD, equivalent to a $6.4 \%$ change, approximately doubles the risk of new fractures at any site. ${ }^{59}$ Recent studies have elucidated factors that lead to upper limb fracture. In young girls, high body weight, a previous forearm fracture and low total body areal BMD each independently increase the risk of fracture and similar risk factors have been shown in boys. ${ }^{39}$ Furthermore, those girls with forearm fractures did not show evidence of catch up of their bone mineral content up to four years following fracture..$^{87}$ Girls with forearm fractures have also been shown to have a significantly smaller cross-sectional area at the distal radius, ${ }^{84}$ which coupled with increased body weight, may confer a biomechanical disadvantage and increase the predisposition to fracture following a fall. Time spent viewing television, computer, and video, as a measure of physical inactivity, also has a dose dependent association with wrist and forearm fractures. ${ }^{88}$ Taken together, these findings indicate that overweight children should be advised to take measures to reduce their weight while increasing physical activity levels in an attempt to optimise their bone health.

While exercise increases bone mass in children, the influence of physical activity levels on fractures in this age group is less clear. Sports participation, particularly contact sports, has been shown to increase upper limb fracture risk in boys, whereas the risk was decreased in girls. Moreover, the fracture risk was decreased in both sexes when undertaking light physical activity ${ }^{88}$ These gender discordant effects may have been the result of the difference in attitude to sport between the sexes.

\section{SUMMARY}

Childhood growth represents a critical period for the acquisition of bone mass. Although genetic influences are the predominant determinant of bone mass, it is only environmental influences which may be modified to optimise bone mass in childhood. Promoting a healthy lifestyle, including regular high impact and/or weight bearing physical activity together with a healthy diet containing optimal calcium and vitamin D intake, may prove the best way to achieve maximal peak bone mass. The recognition by paediatricians of such factors which influence bone mass in childhood is important. They can advise children and their families accordingly and influence public health policies which may lead to an improvement in children's diets and levels of habitual physical activity, thus reducing the risks of osteoporosis and fractures in later life.

\section{Authors' affiliations \\ J H Davies, B A J Evans, J W Gregory, Department of Child Health, Cardiff University, UK}

Competing interests: none declared

\section{REFERENCES}

1 Hollingworth W, Todd CJ, Parker MJ. The cost of treating hip fractures in the twenty first century. J Public Health Med 1995;17:269-76.

2 Chan GM, Hess M, Hollis J, et al. Bone mineral status in childhood accidental fractures. Am J Dis Child 1984; 138:569-70.

3 Goulding A, Jones IE, Taylor RW, et al. Bone mineral density and body composition in boys with distal forearm fractures: a dual-energy $x$-ray absorptiometry study. J Pediatr 2001;139:509-15. 
4 Rauch F, Schoenau E. The developing bone: slave or master of its cells and molecules? Pediatr Res 2001;50:309-14.

5 Matkovic V, Jelic T, Wardlaw GM, et al. Timing of peak bone mass in Caucasian females and its implication for the prevention of osteoporosis. Inference from a cross-sectional model. J Clin Invest 1994;93:799-808.

6 Theintz G, Buchs B, Rizzoli R, et al. Longitudinal monitoring of bone mass accumulation in healthy adolescents: evidence for a marked reduction after 16 years of age at the levels of lumbar spine and femoral neck in female subjects. J Clin Endocrinol Metab 1992;75:1060-5.

7 Gilsanz V, Gibbens DT, Roe TF, et al. Vertebral bone density in children: effect of puberty. Radiology 1988;166:847-50.

8 Neu CM, Manz F, Rauch F, et al. Bone densities and bone size at the distal radius in healthy children and adolescents: a study using peripheral quantitative computed tomography. Bone $2001 ; 28: 227-32$

9 Fewtrell MS. British Paediatric \& Adolescent Bone Group. Bone densitometry in children assessed by dual $x$ ray absorptiometry: uses and piffalls. Arch Dis Child 2003:88:795-8.

10 Lu PW, Cowell CT, LLoyd-Jones SA, et al. Volumetric bone mineral density in normal subjects, aged 5-27 years. J Clin Endocrinol Metab 1996;81:1586-90.

11 Remer T, Boye KR, Hartmann M, et al. Adrenarche and bone modeling and remodeling at the proximal radius: weak androgens make stronger cortical bone in healthy children. J Bone Miner Res 2003;18:1539-46.

12 Daly RM, Saxon L, Turner CH, et al. The relationship between muscle size and bone geometry during growth and in response to exercise. Bone 2004;34:281-7.

13 Recker RR, Davies KM, Hinders SM, et al. Bone gain in young adult women. JAMA 1992;268:2403-8.

14 Ralston SH. The genetics of osteoporosis. QJM 1997;90:247-51.

15 Gueguen R, Jouanny P, Guillemin F, et al. Segregation analysis and variance components analysis of bone mineral density in healthy families. J Bone Miner Res 1995; 10:2017-22.

16 Seeman E, Hopper JL, Bach LA, et al. Reduced bone mass in daughters of women with osteoporosis. N Engl J Med 1989;320:554-8.

17 Soroko SB, Barrett-Connor E, Edelstein SL, et al. Family history of osteoporosis and bone mineral density at the axial skeleton: the Rancho Bernardo Study. $J$ Bone Miner Res 1994;9:761-9.

18 Morrison NA, Qi JC, Tokita A, et al. Prediction of bone density from vitamin D receptor alleles. Nature 1994:367:284-7.

19 Cooper GS, Umbach DM. Are vitamin D receptor polymorphisms associated with bone mineral density? A meta-analysis. J Bone Miner Res 1996:11:1841-9.

20 Sainz J, Van Tornout JM, Loro ML, et al. Vitamin D-receptor gene polymorphisms and bone density in prepubertal American girls of Mexican descent. N Engl J Med 1997;337:77-82.

21 Ferrari SL, Rizzoli R, Slosman DO, et al. Do dietary calcium and age explain the controversy surrounding the relationship between bone mineral density and vitamin D receptor gene polymorphisms? J Bone Miner Res 1998; 13:363-70.

22 Grant SF, Reid DM, Blake G, et al. Reduced bone density and osteoporosis associated with a polymorphic Spl binding site in the collagen type I alpha 1 gene. Nat Genet 1996;14:203-5.

23 Sainz J, Van Tornout JM, Sayre J, et al. Association of collagen type 1 alphal gene polymorphism with bone density in early childhood. J Clin Endocrinol Metab 1999;84:853-5.

24 Lorentzon $\mathrm{M}$, Lorentzon $\mathrm{R}$, Backstrom $\mathrm{T}$, et al. Estrogen receptor gene polymorphism, but not estradiol levels, is related to bone density in healthy adolescent boys: a cross-sectional and longitudinal study. J Clin Endocrinol Metab 1999;84:4597-601

25 Lorentzon $M$, Lorentzon R, Nordstrom P. Interleukin-6 gene polymorphism is related to bone mineral density during and after puberty in healthy white males: a cross-sectional and longitudinal study. J Bone Miner Res 2000;15:1944-9.

26 Gustavsson A, Nordstrom P, Lorentzon R, et al. Osteocalcin gene polymorphism is related to bone density in healthy adolescent females. Osteoporos Int 2000;1 1:847-51

27 Boyden LM, Mao J, Belsky J, et al. High bone density due to a mutation in LDL receptor-related protein 5. N Engl J Med 2002;346:1513-21.

28 Gong $\mathrm{Y}$, Slee RB, Fukai N, et al. LDL receptor-related protein 5 (LRP5) affects bone accrual and eye development. Cell 2001;107:513-23.

29 Johnson ML, Gong G, Kimberling W, et al. Linkage of a gene causing high bone mass to human chromosome 11 (1 lq12-13). Am J Hum Genet 1997:60:1326-32.

30 Little RD, Carulli JP, Del Mastro RG, et al. A mutation in the LDL receptorrelated protein 5 gene results in the autosomal dominant high-bone-mass trait. Am J Hum Genet 2002;70:11-19.

31 Hartikka HM, Makitie O, Mannikko $M$, et al. Heterozygous mutations in the LRP5 gene cause primary osteoporosis in children. Endocrine Society 2004:ORS32-1.

32 Cooper C, Cawley M, Bhalla A, et al. Childhood growth, physical activity, and peak bone mass in women. J Bone Miner Res 1995;10:940-7.

33 Dennison EM, Arden NK, Keen RW, et al. Birthweight, vitamin D receptor genotype and the programming of osteoporosis. Paediatr Perinat Epidemiol 2001;15:211-19.

34 Cooper C, Eriksson JG, Forsen T, et al. Maternal height, childhood growth and risk of hip fracture in later life: a longitudinal study. Osteoporos Int 2001; 12:623-9.

35 Fall C, Hindmarsh P, Dennison E, et al. Programming of growth hormone secretion and bone mineral density in elderly men: a hypothesis. J Clin Endocrinol Metab 1998:83:135-9.
36 Dennison EM, Hindmarsh PC, Kellingray S, et al. Growth hormone predicts bone density in elderly women. Bone 2003;32:434-40.

37 Kajantie E, Phillips DI, Andersson S, et al. Size at birth, gestational age and cortisol secretion in adult life: foetal programming of both hyper- and hypocortisolism? Clin Endocrinol 2002;57:635-41.

38 Dennison E, Hindmarsh P, Fall C, et al. Profiles of endogenous circulating cortisol and bone mineral density in healthy elderly men. J Clin Endocrinol Metab 1999:84:3058-63.

39 Godfrey K, Walker-Bone K, Robinson S, et al. Neonatal bone mass: influence of parental birthweight, maternal smoking, body composition, and activity during pregnancy. J Bone Miner Res 2001;16:1694-703.

40 Mehta G, Roach HI, Langley-Evans S, et al. Intrauterine exposure to a maternal low protein diet reduces adult bone mass and alters growth plate morphology in rats. Calcif Tissue Int 2002;71:493-8.

41 Oreffo RO, Lashbrooke B, Roach $\mathrm{HI}$, et al. Maternal protein deficiency affects mesenchymal stem cell activity in the developing offspring. Bone 2003;33:100-7.

42 Boot AM, Engels MA, Boerma GJ, et al. Changes in bone mineral density, body composition, and lipid metabolism during growth hormone $(\mathrm{GH})$ treatment in children with GH deficiency. J Clin Endocrinol Metab 1997; 82:2423-8

43 Shalet SM, Shavrikova E, Cromer M. Effect of growth hormone (GH) treatment on bone in postpubertal GH-deficient patients: a 2-year randomized, controlled, dose-ranging study. J Clin Endocrinol Metab 2003;88:4124-9.

44 Wang Q, Nicholson PH, Suuriniemi $M$, et al. Relationship of sex hormones to bone geometric properties and mineral density in early pubertal girls. J Clin Endocrinol Metab 2004;89:1698-703.

45 Zanker CL, Gannon L, Cooke CB, et al. Differences in bone density, body composition, physical activity, and diet between child gymnasts and untrained children 7-8 years of age. J Bone Miner Res 2003;18:1043-50.

46 MacKelvie KJ, McKay HA, Petit MA, et al. Bone mineral response to a 7month randomized controlled, school-based jumping intervention in 121 prepubertal boys: associations with ethnicity and body mass index. J Bone Miner Res 2002;17:834-44.

47 MacKelvie KJ, Petit MA, Khan KM, et al. Bone mass and structure are enhanced following a 2-year randomized controlled trial of exercise in prepubertal boys. Bone 2004; 34:755-64.

48 Fuchs RK, Bauer JJ, Snow CM. Jumping improves hip and lumbar spine bone mass in prepubescent children: a randomized controlled trial. J Bone Miner Res 2001;16:148-56.

49 MacKelvie KJ, Khan KM, Petit MA, et al. A school-based exercise intervention elicits substantial bone health benefits: a 2-year randomized controlled trial in girls. Pediatrics 2003; 112:e447-52.

50 Petit MA, McKay HA, MacKelvie KJ, et al. A randomized school-based jumping intervention confers site and maturity-specific benefits on bone structural properties in girls: a hip structural analysis study. J Bone Miner Res 2002; 17:363-72

51 Kannus $\mathbf{P}$, Haapasalo $H$, Sankelo $M$, et al. Effect of starting age of physical activity on bone mass in the dominant arm of tennis and squash players. Ann Intern Med 1995; 123:27-31.

52 Welten DC, Kemper HC, Post GB, et al. Weight-bearing activity during youth is a more important factor for peak bone mass than calcium intake. $J$ Bone Miner Res 1994;9:1089-96.

53 Karlsson MK, Linden C, Karlsson C, et al. Exercise during growth and bone mineral density and fractures in old age. Lancet 2000;355:469-70.

54 Pajamaki I, Kannus P, Vuohelainen T, et al. The bone gain induced by exercise in puberty is not preserved through a virtually life-long deconditioning: a randomized controlled experimental study in male rats. J Bone Miner Res 2003;18:544-52.

55 Bachrach LK, Katzman DK, Litt IF, et al. Recovery from osteopenia in adolescent girls with anorexia nervosa. J Clin Endocrinol Metab $1991 ; 72: 602-6$.

56 Biller BM, Saxe V, Herzog DB, et al. Mechanisms of osteoporosis in adult and adolescent women with anorexia nervosa. J Clin Endocrinol Metab 1989:68:548-54.

57 LeRoith D, Butler AA. Insulin-like growth factors in pediatric health and disease. J Clin Endocrinol Metab 1999;84:4355-61.

58 Golden NH, Kreitzer P, Jacobson MS, et al. Disturbances in growth hormone secretion and action in adolescents with anorexia nervosa. J Pediatr 1994; 125:655-60.

59 Goulding A, Jones IE, Taylor RW, et al. More broken bones: a 4-year double cohort study of young girls with and without distal forearm fractures. J Bone Miner Res 2000;15:2011-18.

60 Blum WF, Englaro P, Hanitsch S, et al. Plasma leptin levels in healthy children and adolescents: dependence on body mass index, body fat mass, gender, pubertal stage, and testosterone. J Clin Endocrinol Metab 1997;82:2904-10.

61 Garcia-Mayor RV, Andrade MA, Rios M, et al. Serum leptin levels in normal children: relationship to age, gender, body mass index, pituitary-gonadal hormones, and pubertal stage. J Clin Endcrinol Metab 1997;82:2849-55.

62 Caro JF, Sinha MK, Kolaczynski JW, et al. Leptin: the tale of an obesity gene. Diabetes 1996;45:1455-62

63 Clement K, Vaisse C, Lahlou N, et al. A mutation in the human leptin receptor gene causes obesity and pituitary dysfunction. Nature 1998;392:398-401.

64 Montague CT, Farooqi IS, Whitehead JP, et al. Congenital leptin deficiency is associated with severe early-onset obesity in humans. Nature 1997;387:903-8.

65 Landt M, Parvin CA, Wong M. Leptin in cerebrospinal fluid from children: correlation with plasma leptin, sexual dimorphism, and lack of protein binding. Clin Chem 2000;46:854-8.

66 Ducy $\mathrm{P}$, Amling $M$, Takeda $S$, et al. Leptin inhibits bone formation through a hypothalamic relay: a central control of bone mass. Cell 2000;100:197-207. 
67 Takeda S, Elefteriou F, Levasseur R, et al. Leptin regulates bone formation via the sympathetic nervous system. Cell 2002;111:305-17.

68 Thomas T, Gori F, Khosla S, et al. Leptin acts on human marrow stromal cells to enhance differentiation to osteoblasts and to inhibit differentiation to adipocytes. Endocrinology 1999;140:1630-8.

69 Gordeladze JO, Drevon CA, Syversen U, et al. Leptin stimulates human osteoblastic cell proliferation, de novo collagen synthesis, and mineralization: impact on differentiation markers, apoptosis, and osteoclastic signaling. J Cell Biochem 2002;85:825-36.

70 Sandler RB, Slemenda CW, LaPorte RE, et al. Postmenopausal bone density and milk consumption in childhood and adolescence. Am J Clin Nutr 1985;42:270-4.

71 Cadogan J, Eastell R, Jones N, et al. Milk intake and bone mineral acquisition in adolescent girls: randomised, controlled intervention trial. $B M J$ 1997;315:1255-60

72 Recker RR, Davies KM, Hinders SM, et al. Bone gain in young adult women. JAMA 1992;268:2403-8.

73 Johnston CC Jr, Miller JZ, Slemenda CW, et al. Calcium supplementation and increases in bone mineral density in children. N Engl J Med 1992:327:82-7.

74 Specker B, Binkley T. Randomized trial of physical activity and calcium supplementation on bone mineral content in 3- to 5-year-old children. J Bone Miner Res 2003; 18:885-92.

75 Bonjour JP, Carrie AL, Ferrari S, et al. Calcium-enriched foods and bone mass growth in prepubertal girls: a randomized, double-blind, placebo-controlled trial. J Clin Invest 1997;99:1287-94.

76 Bonjour JP, Chevalley T, Ammann P, et al. Gain in bone mineral mass in prepubertal girls 3.5 years after discontinuation of calcium supplementation: a follow-up study. Lancet 2001;358:1208-12

77 Rowe PM. Why is rickets resurgent in the USA? Lancet 2001;357:1100.
78 Shaw NJ, Pal BR. Vitamin D deficiency in UK Asian families: activating a new concern. Arch Dis Child 2002;86:147-9.

79 Allgrove J. Is nutritional rickets returning? Arch Dis Child 2004;89:699-701.

80 Gartner LM, Greer FR. Prevention of rickets and vitamin D deficiency: new guidelines for vitamin D intake. Pediatrics 2003;111:908-10.

81 Zamora SA, Rizzoli R, Belli DC, et al. Vitamin D supplementation during infancy is associated with higher bone mineral mass in prepubertal girls. J Clin Endocrinol Metab 1999:84:4541-4.

82 Muhlbaver RC, Li F. Effect of vegetables on bone metabolism. Nature 1999;401:343-4.

83 McGartland C, Robson PJ, Murray L, et al. Carbonated soft drink consumption and bone mineral density in adolescence: the Northern Ireland Young Hearts project. J Bone Miner Res 2003;18:1563-9.

84 Skaggs DL, Loro ML, Pitukcheewanont $P$, et al. Increased body weight and decreased radial cross-sectional dimensions in girls with forearm fractures. J Bone Miner Res 2001;16:1337-42.

$85 \mathrm{Ma} \mathrm{D}$, Jones $\mathrm{G}$. The association between bone mineral density, metacarpal morphometry, and upper limb fractures in children: a population-based casecontrol study. J Clin Endocrinol Metab 2003;88:1486-91.

86 Khosla S, Melton $\amalg$ 3rd, Dekutoski MB, et al. Incidence of childhood distal forearm fractures over 30 years: a population-based study. JAMA 2003;290: 1479-85

87 Jones IE, Taylor RW, Williams SM, et al. Four-year gain in bone mineral in girls with and without past forearm fractures: a DXA study. J Bone Miner Res 2002; 17:1065-72.

$88 \mathrm{Ma} \mathrm{D}$, Jones G. Television, computer, and video viewing; physical activity; and upper limb fracture risk in children: a population-based case control study. J Bone Miner Res 2003;18:1970-7.

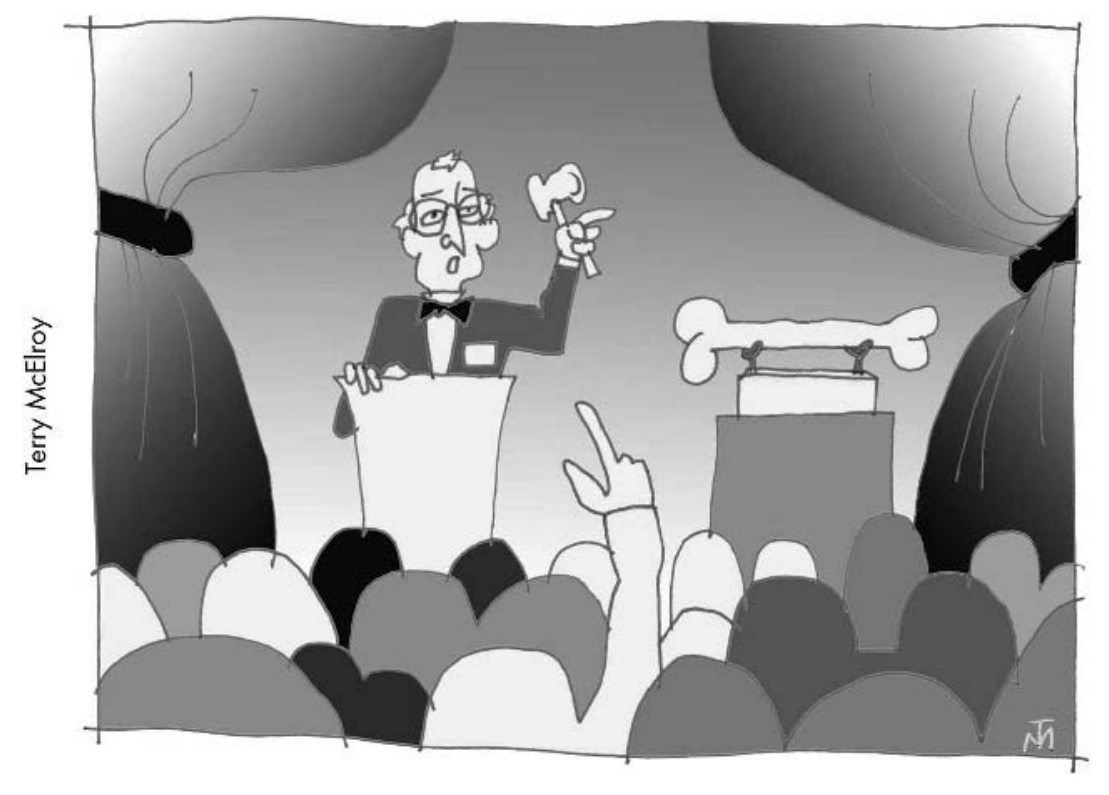

